\title{
Effect of Socio-Economic Status on Coping Behaviour of Female Adolescents
}

\author{
Tauqeer Iqbal $^{1 *}$, Ashfia Nishat ${ }^{2}$
}

\section{ABSTRACT}

The objective of present study is to access the coping strategies of adolescent girls coming from low, middle and high socioeconomic status (SES). This research comprised of 201 female students who completed the Youth coping response inventory (YCRI) and Kuppuswammy Socio Economic Status scale. One Way Analysis was used to analyse the data. The results revealed significant differences among different groups of SES on diversion $(\mathrm{F}=31.625, \mathrm{p}<.001)$, destructive $(\mathrm{F}=30.377, \mathrm{p}<.001)$ and YCRI $(\mathrm{F}=3.220, \mathrm{p}<.05)$. Implications: The study reported that individuals high on SES have positive coping strategies whereas individuals low on SES have negative coping strategies. Therefore, it is implicated that school students coming from lower SES need counselling services as they are having high rate of maladjusted coping behaviour. School management must develop programs in order to facilitate such adolescents and provide a platform with healthy competition and impartial academic growth.

Keywords: Socio-Economic Status (SES), Coping behaviour, Adolescents, Female.

The most prevalent source of daily stress for adolescents are school-related problems; peer group pressures, family issues; their own emotions or behaviours, for instance feeling depressed or aggressive, getting into trouble with parents or school authorities because of their behaviour. Moreover, some adolescents may have to deal with matters that their peers may not have to face depending upon the environment in which they are nurtured. Adolescents belonging to lower income group may have to face different set of challenges for instance poor health due to malnourishment or working in various settings after school to support their parents in generating income, such challenges would not be faced by adolescents coming from high income groups. Adolescents belonging to the high-income groups are more stressed by career options, modernization and materialistic desires. Therefore it is assumed that coping behaviour would

\footnotetext{
${ }^{1}$ Research Scholar, Department of Psychology, Aligarh Muslim University, Aligarh, India

${ }^{2}$ Research Scholar, Department of Psychology, Aligarh Muslim University, Aligarh, India

*Responding Author

Received: March 12, 2017; Revision Received: March 29, 2017; Accepted: March 30, 2017

(C) 2017 Iqbal T, Nishat A; licensee IJIP. This is an Open Access Research distributed under the terms of the Creative Commons Attribution License (www.creativecommons.org/licenses/by/2.0), which permits unrestricted use, distribution, and reproduction in any Medium, provided the original work is properly cited.
} 


\section{Effect of Socio-Economic Status on Coping Behaviour of Female Adolescents}

also vary across different groups. Very few Indian studies have tapped this population's socio economic status (SES) and its effect on coping behaviour.

\section{Coping Behaviour}

Coping is a self-regulatory process, and the type of coping skills an individual can demonstrate will depend on the developmental level and the internal and external resources that are available to an individual. The development of coping skills in adolescence is critical in helping youth maintain positive adaptation to stressors. (Compas, Connor-Smith, Saltzman, Thomsen \& Wasdworth, 2001). Broadly, the two main coping strategies used to deal with stress are problemfocused and emotion-focused strategies. Problem-focused strategies are active problem solving methods used to resolve the stressful relationship between the self and the environment (Compas, Connor-Smith, Saltzman, Thomsen \& Wasdworth, 2001). Emotion-focused coping strategies are those ways in which people achieve an optimal level of emotional regulation and the capacity to deal with intense situations and feelings (Saarni, 1999). Emotion-focused coping strategies can be distraction, information seeking behaviour or cognitive reframing the meaning of the difficult situations. The important feature to these coping strategies is the ability to be flexible in the selection of strategies depending on the stressor and the individuals ability to controll it (Saarni, 1999).Optimal self-regulation occurs when individual allows emotional regulation and active solving are used together to appraise a situation and make sense of what is going on. Moreover, optimal regulation will be attained by using effective coping strategies that will increase the capacity to tolerate challenging situations and negative emotions.

Studies suggest that relationship between SES and stress is present throughout the socioeconomic gradient (Goodman, Ewen, Dolan, Schafer-Kalkheff and Adler, 2005). One explanation for this pattern is that individuals lower down the SES rank have fewer material and psychological resources for meeting the stress of the increasingly challenging environment. The scarcity of these resources may negatively impact physical and psychological well-being. Gallo and Matthews have suggested that the relative lack of resources could possibly be due to hampered coping resources or depletion with lack of substitution of other existing resources( Gallo, Matthews, 2005).So far, few studies have examined the "reserve capacity" hypothesis among adolescents (Gallow, Matthews, 2003; Wills, McNamera, Vaccaro, 1995)despite the fact that adolescence is a crucial developmental phase in which behavioural and patterns are formed and then carried forward into adulthood.

\section{Aim:}

- To study coping strategy among adolescents from different socio economic status.

\section{Objectives:}

- To study coping strategies among individuals from high SES level.

- To study coping strategies among individuals from middle SES level.

- To study coping strategies among individuals from low SES level.

(c) The International Journal of Indian Psychology, ISSN 2348-5396 (e) | ISSN: 2349-3429 (p) | 


\section{METHODS}

\section{Sample and procedure:}

Two hundred and one females from lower to upper socio economic status (SES) from various secondary high schools in Aligarh (India) participated in this study through stratified random sampling. Participant's age ranged from 13-19 years. Scale was administered on subjects with their consent. After obtaining permission from the school authorities and the participants, survey questionnaires were distributed to different classes identified as samples in the study. Adolescents were asked to complete measures during class time supervised by the researcher. Monthly income of the family:

Group - 1: below Rs. 10,000/-

Group - 2: Rs. 10,000/- to Rs. 30,000/-

Group - 3: above Rs. 30,000/-

\section{Measures}

Youth Coping Response Inventory (Hernandez, Vigna, \& Kelley, 2010).The YCRI is a 44item self-report measure of coping strategies. Items are rated on a four-point Likert scale ranging from 1 ("Never") to 4 ("Almost Always"). This scale yields three factors related to coping for youth: Diversion, Destructive Coping, and Ameliorative Coping. Diversion, measures coping strategies an individual uses to focus their attention away from the problem. Destructive Coping includes both destruction of property and self-destructive coping strategies. And finally 11 Ameliorative Coping, measures an individual's use of problem-solving and emotional expression. It should be noted that although the reliabilities are high and meet generally accepted criteria for use with group data $(\alpha=.80)$, they are slightly lower than what would be accepted for use in making decisions about individuals (ideally $\alpha=.95$; DeVellis, 2003; Nunnally \& Bernstein, 1994).

Factor I, Diversion, included items assessing family routines and support, positive thinking, spirituality, and distraction. Strongly related to positive adjustment in the participants. It appears that most coping strategies on this factor represent ways in which youth divert their attention from a problem.

Factor II, Destructive Coping, assessed the most maladaptive coping responses. Methods address both self-destructive coping as well as physically destructive coping. This factor was strongly related to psychological distress, but negatively correlated with psychological adjustment.

Factor III, Ameliorative Coping, included coping mechanisms that attempt to ameliorate the problem either through problem-solving or through attempts to express one's emotions about the problem. It was not expected that problem-focused coping and emotional expression would cluster together on the same factor, previous literature generally distinguishes between problem- 


\section{Effect of Socio-Economic Status on Coping Behaviour of Female Adolescents}

focused and emotion-focused coping; however, Vernberg and colleagues (1996) also found that these two coping styles loaded together in their analysis of the Kidcope.

Kuppuswammy Socio Economic Status scale (Kuppuswammy 1981) revised version 2014: The original scale was published in the year 1981, it incorporates three characteristics to be assessed and scored: Education level of the head of family (HOF), occupation of the HOF, and income per month. It attempts to measure the SES of an individual in a urban region. Its revision was important as inflation means the currency does not retain the same value each year in terms of the goods/services that may be purchased with the same amount.

\section{Statistical Analysis}

The data were analyzed using Statistical Package for Social Sciences (SPSS) 20 for Windows. Prior to data entry, every form was thoroughly checked for completeness and consistency. Descriptive statistics (including means and standard deviations) were calculated for all scales and subscales. All the assumptions of One-way ANOVA were checked and results were found to be satisfactory before the analysis was conducted.

\section{RESULTS}

Table 1: Descriptive Statistics of the Study Variables.

\begin{tabular}{|l|l|l|l|l|l|}
\hline & & N & Mean & SD & SEM \\
\hline Diversion & 1 & 67 & 53.00 & 8.485 & 1.037 \\
\hline & 2 & 67 & 58.07 & 5.927 & .724 \\
\hline & 3 & 67 & 62.75 & 6.625 & .809 \\
\hline Destructive & 1 & 67 & 32.70 & 5.217 & .637 \\
\hline & 2 & 67 & 26.82 & 6.105 & .746 \\
\hline & 3 & 67 & 25.82 & 5.193 & .634 \\
\hline Ameliorative & 1 & 67 & 33.61 & 3.969 & .485 \\
\hline & 2 & 67 & 34.06 & 4.400 & .538 \\
\hline & 3 & 67 & 34.66 & 4.066 & .497 \\
\hline YCRI & 1 & 67 & 119.34 & 12.155 & 1.485 \\
\hline & 2 & 67 & 119.03 & 10.108 & 1.235 \\
\hline & 3 & 67 & 123.21 & 9.395 & 1.148 \\
\hline
\end{tabular}

1= Low SES, 2= Middle SES \& 3= High SES

Table 2 Summary of One Way ANOVA among Different Groups.

\begin{tabular}{|l|l|l|l|l|l|l|}
\hline Variables & $\begin{array}{l}\text { Source of } \\
\text { Variations }\end{array}$ & $\begin{array}{l}\text { Sum } \\
\text { of Squares }\end{array}$ & df & $\begin{array}{l}\text { Mean } \\
\text { Square }\end{array}$ & F & Sig. \\
\hline Diversion & $\begin{array}{l}\text { Between } \\
\text { Groups }\end{array}$ & 3183.970 & 2 & 1591.985 & 31.625 & .000 \\
\hline & $\begin{array}{l}\text { Within } \\
\text { Groups }\end{array}$ & 9967.313 & 198 & 50.340 & & \\
\hline
\end{tabular}

(C) The International Journal of Indian Psychology, ISSN 2348-5396 (e) | ISSN: 2349-3429 (p) | 154 
Effect of Socio-Economic Status on Coping Behaviour of Female Adolescents

\begin{tabular}{|l|l|l|l|l|l|l|}
\hline Variables & $\begin{array}{l}\text { Source of } \\
\text { Variations }\end{array}$ & $\begin{array}{l}\text { Sum } \\
\text { of Squares }\end{array}$ & df & $\begin{array}{l}\text { Mean } \\
\text { Square }\end{array}$ & F & Sig. \\
\hline Destructive & $\begin{array}{l}\text { Between } \\
\text { Groups }\end{array}$ & 1851.970 & 2 & 925.985 & 30.377 & .000 \\
\hline & $\begin{array}{l}\text { Within } \\
\text { Groups }\end{array}$ & 6035.731 & 198 & 30.483 & & \\
\hline Ameliorative & $\begin{array}{l}\text { Between } \\
\text { Groups }\end{array}$ & 36.816 & 2 & 18.408 & 1.069 & .345 \\
\hline & $\begin{array}{l}\text { Within } \\
\text { Groups }\end{array}$ & 3408.776 & 198 & 17.216 & & \\
\hline YCRI & $\begin{array}{l}\text { Between } \\
\text { Groups }\end{array}$ & 725.980 & 2 & 362.990 & 3.220 & .042 \\
\hline & $\begin{array}{l}\text { Within } \\
\text { Groups }\end{array}$ & 22320.119 & 198 & 112.728 & & \\
\hline
\end{tabular}

Table 3 Multiple Comparison of Means for Different Groups on Study Variables.

\begin{tabular}{|l|l|l|l|l|l|l|l|}
\hline $\begin{array}{l}\text { Dependent } \\
\text { Variable }\end{array}$ & $\begin{array}{l}\text { (I) socio } \\
\text { economic } \\
\text { status }\end{array}$ & $\begin{array}{l}\text { (J) socio } \\
\text { economic } \\
\text { status }\end{array}$ & $\begin{array}{l}\text { Mean } \\
\text { Difference } \\
\text { (I-J) }\end{array}$ & $\begin{array}{l}\text { Std. } \\
\text { Error }\end{array}$ & Sig. & $\begin{array}{l}\text { Lower } \\
\text { Bound }\end{array}$ & $\begin{array}{l}\text { Upper } \\
\text { Bound }\end{array}$ \\
\hline Diversion & 1 & 2 & $-5.075^{*}$ & 1.226 & .000 & -8.10 & -2.05 \\
\hline & 1 & 3 & $-9.746^{*}$ & 1.226 & .000 & -12.77 & -6.72 \\
\hline & 2 & 3 & $-4.672^{*}$ & 1.226 & .001 & -7.70 & -1.65 \\
\hline Destructive & 1 & 2 & $5.881^{*}$ & .954 & .000 & 3.53 & 8.23 \\
\hline & 1 & 3 & $6.881^{*}$ & .954 & .000 & 4.53 & 9.23 \\
\hline & 2 & 3 & 1.000 & .954 & .578 & -1.35 & 3.35 \\
\hline YCRI & 1 & 2 & .313 & 1.834 & .986 & -4.21 & 4.84 \\
\hline & 1 & 3 & -3.866 & 1.834 & .111 & -8.39 & .66 \\
\hline & 2 & 3 & -4.179 & 1.834 & .077 & -8.70 & .35 \\
\hline
\end{tabular}

The results revealed significant differences among different groups of SES on diversion $(\mathrm{F}=31.625, \mathrm{p}<.001)$, destructive $(\mathrm{F}=30.377, \mathrm{p}<.001)$ and $\mathrm{YCRI}(\mathrm{F}=3.220, \mathrm{p}<.05)$.

Tukey Post hoc test (Table 3) was applied for comparing the means of different groups of SES on the study variables where significant differences among the groups were observed. A perusal of values in tables 1 and 3 indicates that high SES group scored better on diversion ( $M=62.75)$ than middle $(M=58.07)$ and lower SES $(M=53.00)$ while, in destructive, high SES group $(M=$ 25.82) scored lower than middle $(\mathrm{M}=26.82)$ and lower SES $(\mathrm{M}=32.70)$. While taking YCRI, high SES group scored better than middle and lower SES, though the difference was not significant.

(c) The International Journal of Indian Psychology, ISSN 2348-5396 (e)| ISSN: 2349-3429 (p) | 155 


\section{DISCUSSION}

Aim of the present research was to examine the effect of socio economic status on youth coping behaviour. The above result exhibits that females from high SES have better coping responses in the area of diversion as compared to those who belong to middle and low SES backgrounds. And similarly, females adolescents from middle SES have better diversion coping responses when compared with low SES, this could be due to the availability of resources which promote diversion coping like watching TV, playing games or reading, getting involved in activities like sports, dance or clubs.

In the area of destructive coping it was found just the reverse, females from high SES were less destructive than females from low SES background. Also participants from middle SES reported lesser destructive coping behaviour when compared with low SES group, a probable reason could be that when family conditions are fragile then it directly affects the members. Those who are deprived economically and are living in disadvantaged neighborhoods face a variety of chronic stressors in daily lives: their parents struggle to make ends meet; find limited opportunities to achieve their aims; experience more negative life events such as unemployment, discrimination and powerlessness (Baum et al. 1999, Lantz et al. 2005, McEwen 1998). Social advantagehas a buffering effect against risk taking behaviours and enhances positive development.

Whereas, there was no significant difference observed between high and middle SES group with regards to destructive coping, a possible reason for this could be that the environment around the individuals coming from middle SES is not as harsh and unfavorable when compared with lower SES group, hence they are able to exercise better coping behaviour in order to express their negative feelings like aggression and disappointments in life.SES plays a crucial role in the life of an individual.

\section{LIMITATIONS OF THIS STUDY}

The sample size was limited only to one city (Aligarh) and restrictions of time and resources; it could not be done in other cities. Thus, the results cannot be generalized. Male sample was not included in the present study.

\section{Acknowledgments}

The author appreciates all those who participated in the study and helped to facilitate the research process.

\section{Conflict of Interests}

The author declared no conflict of interests. 


\section{REFERENCE}

Baum, A., Garofalo, J.P., \&Yali, A.M.(1999). Socioeconomic status and chronic stress: Does stress account for SES effects on health? Annals of the New York Academy Science, 896:131-144. [PubMed: 10681894]

Compas, B. E., Connor-Smith, J. K., Saltzman, H., Thomsen, A. H., \& Wadsworth, M. E. (2001). Coping with Stress During Childhood and Adolescence: Problems, Progress, and Potential in Theory and Research. Psychological Bulletin,127:87-127. [PubMed]

DeVellis, R.F. (2003). Scale development: Theory and applications (2nd ed.). London: Sage.

Flier, Jeffrey S., Underhill, Lisa H., McEwen, Bruce S. (1998). "Protective and Damaging Effects of Stress Mediators". New England Journal of Medicine. 338 (3): 171-9.

Gallo, L.C., \& Matthews, K.A.(2003). Understanding The Association Between Socioeconomic Status And Physical Health: Do Negative Emotions Play A Role?. Psychological Bulletin 129(1): 10-51. Web.

Goodman, E., Ewen, B. S., Dolan, L. M., Schafer-Kalkhoff , T. \& Adler, N. A. (2005). Social disadvantage and adolescent stress. Journal of Adolescent Health, 37(6), 494-492

Lantz, P.M., House, J.S., Mero, R.P.,\& Williams, D.R. (2005). Stress, life events, and socioeconomic disparities in health: results from the Americans' Changing Lives Study. J. Health Soc. Behav.; 46:274- 288. [PubMed: 16259149]

Nunnally, J.C., \& Bernstein, I.H. (1994). Psychometric Theory (3rd ed.).New York: McGrawHill.

Saarni, C. (1999). The development of emotional competence. New York: Guildford Press.

Sharma, R., Saini, N.K.(2014). A critical appraisal of Kuppuswamy's socioeconomic status scale in the present scenario. J Family Med Prim Care.3:3-4.

Vernberg, E.M., La Greca, A.M., Silverman, W.K., \& Prinstein, M.J. (1996). Prediction of Posttraumatic stress symptoms in children after hurricane Andrew. Journal of Abnormal Psychology, 105, 237-248.

Vigna, J.F., Hernandez, B.C., Kelley, M.L., \& Gresham, F.M. (2010). Coping behavior in hurricane-affected African American youth: Psychometric properties of the Kidcope. Journal of Black Psychology, 36, 98-121.

Wills, T.A., McNamara, G., \&Vaccaro, D. (1995) Parental education related to adolescent stress-coping and substance use development of a mediational model. Health Psychol. 14(5):464-478.

How to cite this article: Iqbal T, Nishat A (2017), Effect of Socio-Economic Status on Coping Behaviour of Female Adolescents, International Journal of Indian Psychology, Volume 4, Issue 2, No. 96, ISSN:2348-5396 (e), ISSN:2349-3429 (p), DIP:18.01.197/20170402, ISBN:978-1365-84232-0 